\title{
IN WITH THE OLD: COMMUNITY PARTICIPATION IN HERITAGE MANAGEMENT IN SELECTED MALAYSIAN TOURIST SITES
}

\author{
Rachel CHAN Suet Kay \\ Institute of Ethnic Studies (KITA), \\ National University of Malaysia (UKM) \\ (rachelchansuetkay@ukm.edu.my) \\ DOI: https://doi.org/10.22452/jati.vol24no2.8
}

\begin{abstract}
Rather than replacing the aged with the brand new, lifestyle producers and consumers are embracing a vintage revival. The rejuvenation of pre-war buildings as tourist attractions has become a recent trend, especially in Petaling Street, a major historical site in the heart of Malaysia's capital city, Kuala Lumpur. However, there is a lack of study on the existing forms of community participation in heritage management among historical tourist sites in Kuala Lumpur. My study addressed this issue through ethnographic fieldwork in Petaling Street's Chinatown, combining participant observation which included site visits, photo-ethnography, and interviews. Surveys, library research, and content analyses were also conducted to supplement this research as part of my overall FRGS project. My study found that in Petaling Street, there are two forms of cultural heritage preservation - firstly, the adaptive reuse of historical buildings; and secondly - the continued use of a historical building. The former consists of heritage-style hipster cafes and locales; while the latter is manifested in the sustenance of a Chinese clan association, Chan See Shu Yuen Kuala Lumpur and Selangor (CSSYKL). The former has been rejuvenated to feed a hipster aesthetic as well as to attract tourists from around the world. Meanwhile, CSSYKL is made up not only of tangible cultural heritage through its century-old building, but also organic intangible cultural heritage which is its Cantonese clan association membership and its practices. Thus, it is apparent that the Asian-based community participation approach to cultural heritage preservation functions in two ways - first, the preservation of tangible and intangible forms of cultural heritage for the benefit of clan association members as well as for tourism purposes; and secondly to fulfil market demand. These two co-existing forms of community participation successfully add value to the cultural identity of Kuala Lumpur in the era of super-diversity.
\end{abstract}

Keywords: Chinese clan associations, Petaling Street Kuala Lumpur, cultural heritage preservation, community participation, super-diversity 


\section{Introduction}

Rather than replacing the aged with the brand new, lifestyle producers and consumers are embracing a vintage revival. This can be seen not only as an act of advocacy but also as aesthetic enjoyment. The tourism and leisure sectors have reignited an interest in reconciliation with heritage. Some buildings are entirely historical in origin, while others are designed to appear so, sparking a movement called facadism, which entails "the preservation of historic facades, the creation of facsimiles in front of new buildings and the decorative exercises of postmodernism" (Richards, 1994). The actual definition of what constitutes "heritage" has been decided by UNESCO, having allocated three categories to it which are tangible, natural, and intangible (Kirshenblatt-Gimblett, 2004).

\section{Table 1: UNESCO Definitions of Heritage}

\begin{tabular}{|l|l|}
\hline \multicolumn{1}{|c|}{ Heritage } & \multicolumn{1}{c|}{ Definition } \\
\hline $\begin{array}{l}\text { Tangible } \\
\text { heritage }\end{array}$ & $\begin{array}{l}\text { A monument, group of buildings, or site of historical, aesthetic, } \\
\text { archaeological, scientific, ethnological or anthropological value. }\end{array}$ \\
\hline $\begin{array}{l}\text { Natural } \\
\text { heritage }\end{array}$ & $\begin{array}{l}\text { Outstanding physical, biological, and geological features, habitats } \\
\text { of threatened plants or animal species and areas of value on } \\
\text { scientific or aesthetic grounds or from the point of view of } \\
\text { conservatism. }\end{array}$ \\
\hline $\begin{array}{l}\text { Intangible } \\
\text { heritage }\end{array}$ & All forms of traditional and popular folk culture. \\
\hline
\end{tabular}

(Source: Kirshenblatt-Gimblett (2004).)

Where tourism is concerned, heritage plays an important part, especially if it has been designed a World Heritage Site (WHS). Tourism started off with a public interest in tangible and natural heritage (Ryan \& Silvanto, 2009), but has since expanded to include intangible heritage, such as cultural festivals and practices. Over time, the WHS designation has evolved from a technical measure adopted to preserve historical sites, into a brand used by countries to attract tourists, possessing the promises of quality and differentiation (Ryan \& Silvanto, 2009). Because of its status as a "destination brand", heritage sites now face the usual branding challenges, as they have the involvement of many stakeholders such as UNESCO, their national governments, tourist boards, merchants, and others (Ryan \& Silvanto, 2009).

In addition, another challenge faced by heritage sites in developing nations is that of intensified urban problems due to rapid economic development and population growth (Shahrul Yani Said, Hasnizan Aksah, \& Elma Dewiyana Ismail, 2013). For example, in Malaysia, many historic cities have been exposed 
to the threat of identity erosion (Shahrul Yani Said et al., 2013). This is because the introduction of new townships has exposed these historic cities to the pressures of "commercialisation, poor design, and cultural uniformity" (Shahrul Yani Said et al., 2013).

Historical buildings in Kuala Lumpur, Malaysia's capital city, have also been sacrificed to make way for urban renewal projects (Al-Obaidi, Sim, Muhammad Azzam Ismail, \& Kam, 2017). Historical buildings, especially privately-owned ones located in Kuala Lumpur's tourist zones have been converted into hotels and cafes to cater to market demand (Al-Obaidi et al., 2017), while others have been reused in different capacities such as museums, libraries, offices, or hotels (Salleh \& Ahmad, 2009). This process is known as adaptive re-use, and incurs some benefits such as increased sustainability and lower costs (Wilkinson \& Reed, 2008) but also creates physical and environmental issues (Al-Obaidi et al., 2017).

\section{Problem Statement, Research Questions and Objectives}

Studies of cultural heritage and tourism in Malaysia took off after 2008, after the listing of Malaysian cities George Town (Penang) and Malacca on the UNESCO World Heritage List. However, there is a lack of study on the existing forms of community participation in heritage management among historical tourist sites in Kuala Lumpur, Malaysia's capital city. In this paper, I demonstrate the case of co-existing urban regeneration and heritage preservation community efforts in Petaling Street, Kuala Lumpur.

\section{Literature Review and Theoretical Framework}

A growing body of opinion supports the view that adaptive reuse is a powerful strategy for urban regeneration and sustainability instead of preservation (Bullen \& Love, 2011). Adaptive reuse involves converting a building to undertake a change of use required by new or existing owners (Latham, 2000; Wilkinson, James, \& Reed, 2009). The change of use may require refurbishment and/or a complete renovation of existing buildings or structures (Bullen \& Love, 2011). These could involve major internal space reorganisation, service upgraded, replacement, or just minor restoration where nothing changes except the building's functional use (Bullen \& Love, 2011). Adaptive reuse conserves the building's original architectural, social, cultural, and historical values (Latham, 2000). Bromley, Tallon, and Thomas (2005) have advocated that an adaptive reuse is essentially a form of heritage conservation (Bullen \& Love, 2011). 
In Al-Obaidi et al. (2017)'s study on the adaptive re-use of heritage shop houses as budget hotels, it was found that several considerations need to be addressed before adaptive re-use can be carried out. These include natural lighting, natural ventilation, the recycling of materials, and water efficiency (AlObaidi et al., 2017). Otherwise, it is likely that the project might encounter a fire, which is one of the greatest threats to heritage buildings, the building's occupants, as well as the building's fabric and contents (Salleh \& Ahmad, 2009). Heritage buildings are vulnerable to fire, due to several factors such as "large scale buildings, flammable priceless contents, a large number of visitors, and existing structures weak in fire resistance" (Salleh \& Ahmad, 2009). Dysart (2006) also compared a series of adaptive re-use initiatives based on factors such as lighting, signage, parking, façade, recognisability of previous structure, elevation, use of space, the heat island effect, water conservation, and ecofriendliness, finding that different initiative performed differently across the elements.

On top of this, there are social consequences to bear in adaptive re-use. There have been incidences where adaptive re-use initiatives had taken a piecemeal approach to conserve only individual buildings regardless of the whole system (Orbasli, 2009). The growth of cafes and restaurants with historical facades also contributes to the formation of the "architectural theme park" where the commodification of leisure and the privileging of tourist needs overrides the needs of residents (Parham, 1996).

Thus, there are arguments for and against adaptive re-use of historical buildings. Wilkinson \& Reed (2008) summarised the arguments for adaptive reuse of existing buildings, arguing for and against it across a few dimensions, namely the social, environmental, economic, and technological ones.

Table 2: Arguments for and Against Adaptive Re-Use Summarised

\begin{tabular}{|l|l|l|}
\hline Social & \multicolumn{1}{|c|}{ For } & \multicolumn{1}{|c|}{ Against } \\
\hline & $\begin{array}{l}\text { Existing buildings represent } \\
\text { social and cultural capital } \\
\text { Wider appreciation and more } \\
\text { enlightened attitude towards } \\
\text { heritage value } \\
\text { Enables revitalisation of } \\
\text { neighbourhoods and controls } \\
\text { urban sprawl } \\
\text { Prevents crime and vandalism } \\
\text { Lends character to a place } \\
\text { For future generations to enjoy }\end{array}$ & $\begin{array}{l}\text { Some building stock is simply } \\
\text { too ugly } \\
\text { Some projects failed to } \\
\text { provide affordable } \\
\text { housing/social mix (failed in } \\
\text { their social objectives) }\end{array}$ \\
\hline
\end{tabular}




\begin{tabular}{|c|c|c|}
\hline Environmental & \begin{tabular}{l}
\multicolumn{3}{l}{ Lower material usage } \\
Lower overall embodied \\
energy
\end{tabular} & None at the moment \\
\hline Economic & $\begin{array}{l}\text { Cheaper than demolition and } \\
\text { rebuilding }\end{array}$ & $\begin{array}{l}\text { Adaptive reuse could be } \\
\text { more expensive } \\
\text { Many existing buildings are } \\
\text { of poor construction quality, } \\
\text { thus raising costs for } \\
\text { remediation } \\
\text { Hidden costs, e.g. loss of } \\
\text { tenants' goodwill, loss of } \\
\text { amenity }\end{array}$ \\
\hline Technological & $\begin{array}{l}\text { Technological changes mean } \\
\text { that buildings can become } \\
\text { obsolete in a short space of } \\
\text { time }\end{array}$ & \\
\hline
\end{tabular}

\section{Source: (Wilkinson \& Reed (2008).)}

Therefore, the decision of whether to consider a building for adaptive re-use entails a complex set of considerations, including heritage preservation, architectural assets, and market trends (Bullen \& Love, 2011). Nonetheless, according to Adlin Baizura Ariffin, Mohd. Salehuddin Mohd. Zahari, Salleh Mohd. Radzi, \& Mohd. Zain Kutut (2017), there is still a lack of study on the consequences of adaptive re-use of historical buildings towards actual tourist visitation.

From the above, it is apparent that it is important to find a balance between conservation and redevelopment in order to preserve a city's identity (Wan Abdullah Zawawi Noor Amila \& Alias Abdullah, 2008 ). Moreover, the bulk of the literature shows that the success of global cities relies increasingly on the distinctiveness of places, rather than on "faceless cities" (Wan Abdullah Zawawi Noor Amila \& Alias Abdullah, 2008). Towns in Malaysia are rich with built heritage from its colonial days and stand as a historic testament to the symbiotic relationship between the dominant ethnic groups in urban areas, namely the Malay and the Chinese (Wan Abdullah Zawawi Noor Amila \& Alias Abdullah, 2008). Indeed, it has been found that ethnic events can help to reinforce a sense of cultural identity and community cohesion, as long as it is not over-commercialised (Smith, 2003). For example, festivals can be used to increase racial tolerance through cross-cultural exchange and education (Smith, 2003). The development of ethnic festivals can sometimes help to raise the profile of local 
community groups, leading to a greater understanding of and interest in their culture (Smith, 2003).

However, unchecked redevelopments are destroying Malaysia's unique multi-cultural heritage (Wan Abdullah Zawawi Noor Amila \& Alias Abdullah, 2013). More often than not, the decisions pertaining to traditional shophouse redevelopment are based on guidelines inherited from the monocultural British system, whose perspectives narrowly represent the multi-cultural society in Malaysia (Wan Abdullah Zawawi Noor Amila \& Alias Abdullah, 2013). This observation has also been made by Shamsul Amri Baharuddin and Athi S. M. (2013) regarding the British epistemological conquest in Malaya where the view of plural society was enforced to divide Malaysians according to ethnic lines. In their study, Wan Abdullah Zawawi Noor Amila and Alias Abdullah (2013) found that even those with similar interests and decision contexts can have divergent views about the relative importance of the decision criteria. Since urban areas are complex and dynamic systems, urban redevelopment is a response to the opportunities and challenges which are manifested by urban decay in a particular space at a specific moment in time (Wan Abdullah Zawawi Noor Amila \& Alias Abdullah, 2013).

In this paper, I argue that the two co-existing forms of community participation in heritage management in Petaling Street, Kuala Lumpur, successfully adds value to the cultural identity of Kuala Lumpur in the era of super-diversity. Super-diversity is a notion intended to underline a level and kind of complexity surpassing anything the country has previously experienced (Vertovec, 1997). It is distinguished by a dynamic interplay of variables among an increased number of immigrants who have arrived over the last decade, who are: new, small and scattered, multiple-origin, transnationally connected, socioeconomically differentiated and legally stratified (Vertovec, 1997). In Vertovec (2007)'s argument, observing ethnicity or country of origin provides a misleading, one-dimensional appreciation of contemporary diversity. It is not enough to see diversity only in terms of ethnicity (Vertovec, 2007). He also calls for examining other dimensions such as "differential immigration statuses and their concomitant entitlements and restrictions of rights", "divergent labour market experiences", "discrete gender and age profiles", "patterns of spatial distribution", and "mixed local area responses by service providers and residents" (Vertovec, 2007). The attributes of new immigrants include net inflows, countries of origin, languages, religions, gender, age, space/place, transnationalism, and migration statuses (e.g. workers, students, spouses and family members, asylum-seekers and refugees, irregular, illegal or undocumented migrants, and new citizens) (Vertovec, 2007). Ultimately, 
Vertovec (2017) emphasised it as a device for drawing attention to new social complexities, or the search for better ways to describe and analyse new social patterns, forms and identities arising from migration-driven diversification (Chan, 2018a, 2018b, 2018c, 2018d). At present, Malaysia has borne witness to more complex changes in its demographic composition. Malaysia's foreign population increased rapidly in the last three decades, with over 0.49 percent out of 13 million citizens in 1980, to 2.3 million or 8.3 percent out of 28.4 million in 2010 (Azizah Kassim, Too, Wong, \& Mahani Zainal Abidin, 2014). In this era, it is more pertinent than ever to echo the United Nations Educational, Scientific and Cultural Organization (UNESCO)'s (2016) observation on the need to maintain social cohesion through cultural heritage preservation.

\section{Methodology}

This study stems from the FRGS project, "Superdiversity Networks: Cantonese Clan Associations in Malaysia as Transnational Social Support System", which examined, in particular, the Chan See Shu Yuen Kuala Lumpur \& Selangor Clan Association (CSSYKL). CSSYKL is an example of a historical heritage building which continues to function today, albeit in an evolved form. Besides being a clan association catering to the needs of its members, CSSYKL is also an important international and local tourist attraction. Upon conducting initial fieldwork, it was observed that CSSYKL is also surrounded by many other heritage buildings, similarly functioning as tourist attraction sites after undergoing adaptive re-use. As a tourist, the sum total of one's experience walking from CSSYKL on one end of Petaling Street, to the other end of Petaling Street with its heritage shophouses, is purely immersive in the city's culture. I would go as far as to phrase it "accumulating cultural capital in Malaysia's cultural capital".

Hence, the scope of research is limited to observing cultural heritage sites whose primary functions are tourism or consumer-oriented. Thus, sacred places such as religious structures or administrative buildings were not covered in this study.

Fieldwork consisted of participant observation which included photography, videography, content analysis of secondary documents, and focus group discussions with the clan's board of directors, staff, and members, and a survey of tourists. I initially conducted interviews with the clan association directors, staff, as well as elders and youth members in order to understand the history of the place and its recent development, while being present on a weekly basis to observe the clan association activities which included celebrating major Chinese festivals such as Chinese New Year, Mid-Autumn Festival, and Qing 
Ming; as well as national events such as Malaysia Day. I recorded these celebrations through photography and videography, noting instances of ethnic diversity in these celebrations. I then moved on to observing tourist behaviour in the CSSYKL heritage building, as well as the surrounding ethnic enclave. With the permission of CSSYKL, I prepared a box containing my questionnaire and signage, inviting tourists to fill up an opinion survey regarding their visit.

To gauge tourists and visitors' actual opinions regarding their visits to the few selected places chosen for observation in this study, I harvested reviews from tourism website TripAdvisor, as it enables tourists to review places they have visited. I selected the three latest reviews regarding building design on the front page of each tourist spot, as of the writing of this article, in July 2019. I have eliminated any identifying information about the tourist reviewers as well as the selected tourist attractions for a reason mentioned above, which is not to prioritise or advertise any business concern and also to protect the reviewers' privacy. Although these reviews are made publicly accessible online by the reviewers, I have considered the issue of privacy and anonymity to be objective and not endorse any particular viewpoint. The reviews are produced in its original form here, but only parts mentioning the tourists' opinion of the building's ambience are selected. Mentions of food and service quality are left out as this is not the scope of the study.

\section{Results}

\section{Analysis and Findings}

Petaling Street is known as Kuala Lumpur's "Chinatown", and is a place of interest to tourists (Mahsa Mansouri \& Norsidah Ujang, 2016). Kuala Lumpur's "Chinatown" (KLC) is one of the most visited tourist sites in Malaysia due to its local heritage and unique character (Toong \& Utaberta, 2015). KLC is not just a stretch of Petaling Street but covers several streets and alleys, e.g. Jalan Sultan, Jalan Hang Lekir, and along Jalan Hang Kasturi (Guelden, 1986; Wong, 2011) (Mahsa Mansouri \& Norsidah Ujang, 2016). Petaling Street is one of the earliest roads and one of the seven streets that Kuala Lumpur had before 1880, where Lam (2004) describes it as "the mother of all markets" and "KL's original shopping centre" (Wong, 2011). Like other "Chinatowns" in the world, KLC has diverse activities and services (Mahsa Mansouri \& Norsidah Ujang, 2016). Besides the markets, street-markets, food stalls, and shops, wet market, and flea market, there are also old shophouses, offices and hotels and several temples in the KLC area (Mahsa Mansouri \& Norsidah Ujang, 2016).

One of the most famous landmark cases of adaptive re-use in Kuala Lumpur, is the Central Market building, on Jalan Hang Kasturi nearby Petaling 
Street. Initially a wet market built in 1936, the Central Market was adapted into an arts and crafts marketplace in 1986 after citizens' groups campaigned to save the building through conservation (Harun, 2011; Yacob Omar \& Nor Haniza Ishak, 2009). It is now known as Pasar Seni (Art Market).

KLC also possesses a stock of pre-war shophouses with differing architectural styles and historical values (Toong \& Utaberta, 2015). As mentioned above, to cater to tourist demand, some owners of these pre-war shophouses have renovated their buildings to suit lifestyle changes, urbanisation, and economic pressures (Toong \& Utaberta, 2015). In their business-oriented outlook, multi-storey hotels, guesthouses, and offices would be more profitable in comparison to pre-war shop houses (Toong \& Utaberta, 2015).

The heritage buildings of Petaling Street are influenced by a combination of Western and Chinese architectural styles. In 1894, the British Resident of colonial Malaya, Frank Swettenham initiated the building of masonry shop houses along Petaling Street (Toong \& Utaberta, 2015). However, these shophouses' features were very much influenced by Southern Chinese architecture (Toong \& Utaberta, 2015). European architecture only influenced the later design and development of these shophouses (Toong \& Utaberta, 2015). Certain aspects of the buildings, such as the verandas, were adapted to the local context, giving rise to a new hybrid style known as the "Southern China Eclectic Style" (Toong \& Utaberta, 2015). However, the verandas are now occupied by street stalls which park in disarray, causing walkability problems for pedestrians (Toong \& Utaberta, 2015). The Chinese shophouse is mainly two to three floors in height, with a certain typical interior layout (Al-Obaidi et al., 2017). The shophouses are built along the street with an established uniform grid (Al-Obaidi et al., 2017). The long rectangular floor plan of shop houses offers a narrow frontage (Al-Obaidi et al., 2017). The ground floor, which faces the street, is for commercial purposes, whereas the rear section and upper floor of shophouses are for private use (AlObaidi et al., 2017). Generally, most private heritage buildings along Jalan Sultan and KL "Chinatown" have been converted into hotels, cafes, bars, and restaurants to fit the modern needs of locals and tourists (Al-Obaidi et al., 2017). Malaysia's tourism statistics stated that there were 25.7 million tourists arrivals in 2015, which contributed RM 69.1 billion to the local economy (Al-Obaidi et al., 2017).

The stylistics of shophouses have hybrid characteristics, incorporating architectural influences from Western, Chinese, and Malay origins (Mahsa Mansouri \& Norsidah Ujang, 2016). The adaptation of Western design only became popular after local exposure to the European culture in the late 19th century (Mahsa Mansouri \& Norsidah Ujang, 2016). Since the 17th century, the 
architectural style of shophouses in Malaysia has evolved through this hybrid combination of influences, including those introduced by the British, such as Moorish, Tudor, neo-classical and neo-Gothic styles (Salleh \& Ahmad, 2009) as well as Chinese styles (Elnokaly \& Wong, 2015). These are outlined below:

1. Southern China style (1700s - 1800s): Earliest Chinese influenced shophouses found in Malacca city. The shophouse embedded the notion of Chinese symbolism to promote spiritual harmonies. The structure is built with lime plastered brick and timber roofing. The architecture has close assembly to Chinese shops in Southern China.

2. Early (1800s - 1850s): Simpler shop house following the Southern China style. Usually built as a double storey with a connected pedestrian arcade. Earlier style has smaller form and facade, constructed with timber. Masonry part walls are adopted.

3. Dutch (1600s - 1700s): Only in Malacca.

4. Early Transitional (1860s)

5. Early Straits Eclectic (1890s)

6. Late Straits Eclectic (1900s)

7. Neo-Classical (1920s)

8. Dutch Patrician (1930s)

9. Art Deco (1930s)

10. Modern (1960s)

11. Utilitarian (1990s)

12. Late Modern (1980s)

13. Contemporary (2000s)

Shophouses which fell under the Modern style from the 1960s onwards were not considered to be historically significant, which is a pity as observed by Mahsa Mansouri \& Norsidah Ujang (2016). This is because these shophouses were thought to lack the unique characteristics of earlier shop houses and had been diluted by mass development (Mahsa Mansouri \& Norsidah Ujang, 2016).

Besides pre-war shophouses, KLC's back lanes are also of interest to tourists. Wan Hashimah Wan Ismail and Jegenth Raj s/o Nadarajah (2016) studied the back lanes used as social spaces in KLC, especially those belonging to old shophouses. Initially, these back lanes were used as backyards, service routes, and fire escape routes for shophouses (Wan Hashimah Wan Ismail \& Jegenth Raj s/o Nadarajah, 2016). However, in KLC, the back lanes have been now utilised for other functions, turning them into social interaction spaces (Wan Hashimah Wan Ismail \& Jegenth Raj s/o Nadarajah, 2016). Wan Hashimah Wan 
Ismail and Jegenth Raj s/o Nadarajah (2016) found that the back lanes of KLC successfully underwent urban regeneration from backstreets into lively alleys (Wan Hashimah Wan Ismail and Jegenth Raj s/o Nadarajah, 2016). Thus, they concluded that back lanes can be considered as part of urban design strategies and not merely as leftover spaces. The evolution of back lanes has slowly contributed to the urbanscape positively, increasing interaction due to its diversity (Wan Hashimah Wan Ismail \& Jegenth Raj s/o Nadarajah, 2016).

In this study, several instances of adaptive re-use of heritage pre-war shophouses have been observed. I visited these places as part of my fieldwork, patronising the businesses involved, talking to the proprietors, accessing more information through the businesses' social media sites and its news coverage, as well as photography and videography of the buildings' aesthetics. However, the buildings are not specifically identified here apart from CSSYKL, to avoid prioritising any business concern over others and to avoid the breaching of privacy.

Table 3: Selected Heritage Locations of the Study

\begin{tabular}{|l|l|l|}
\hline \multicolumn{1}{|c|}{ Place } & \multicolumn{1}{c|}{ Features } \\
\hline 1 & CSSYKL & $\begin{array}{l}\text { A traditional Cantonese clan association building with } \\
\text { tangible heritage (architecture) and intangible heritage (the } \\
\text { Chinese clan association body). }\end{array}$ \\
\hline 3 & Street/back lane & $\begin{array}{l}\text { A cafe which retains the original structure of the pre-war } \\
\text { building in KL. Formerly a brothel several decades ago, but } \\
\text { the aesthetic was maintained as a tourist attraction and } \\
\text { novelty. Specialises in colonial-style cuisine and is a photo- } \\
\text { friendly place for the hipster and social media influencer } \\
\text { crowd. } \\
\text { A back lane of one of Petaling Street's famous roads. } \\
\text { lives in pre-war times. Combines the pre-war vibe of } \\
\text { Chinese back lanes which served as a social space, with } \\
\text { contemporary tourist-friendly features such as being } \\
\text { photo-friendly and caters to tourists, hipsters, and the } \\
\text { social media influencer crowd. }\end{array}$ \\
\hline 4 & $\begin{array}{l}\text { Tea } \\
\text { house/restaurant } \\
\text { expanded as a popular youth hangout selling food and also } \\
\text { offering traditional Chinese tea rituals. Housed in an } \\
\text { adaptive re-use shop house with décor resembling a } \\
\text { traditional Chinese tea house but with a contemporary } \\
\text { bent, featuring also a little art gallery where art classes are } \\
\text { conducted. }\end{array}$ \\
\hline
\end{tabular}


Besides adaptive re-use buildings and structures, there are also traditional Chinese heritage buildings in Petaling Street, such as the tourist attraction and historical site, Chan See Shu Yuen Kuala Lumpur \& Selangor Clan Ancestral Hall (CSSYKL). It is situated on Petaling Street, at the intersection of Lorong Petaling and Jalan Stadium opposite Bulatan Merdeka. CSSYKL was initially set up by a founder of Cantonese origin a century ago to facilitate labour migration from mainland China into British colonial Malaya (Chan, 2019a). Members still maintain relations with the ancestral temple's branch in Guangdong, China, where the building's design originated from (Chan, 2019a). The association is registered with the Malaysian Registrar of Societies.

The Chinese clan association temple is an example of cultural heritage which is situated in the crossroads between tourism and tradition, especially those located in central urban areas (Chan, 2019a). Chinese clan associations used to provide lifelong social, cultural, and economic support to its members. Chinese clan associations can be found in many parts of the world, due to the Chinese emigration from mainland China in the 1800s (Chan, 2019a). Clans are made up of kinship-bound families (Yen, 1981). The clan is a group formed with a patrilineal blood relationship based on a common ancestor at its core (Sun, 2005). Hence, the Chinese clan association is an organisation whose membership includes individuals with the same surname (Ch'ng, cited in Mariana Makmur, 2018). In the past, Chinese clan associations possessed several main functions. These were preserving the family unit, which is of paramount importance to Chinese identity (Sun, 2005); affiliation with one's dialect group; maintaining Confucianism as their main value system, comprising concepts such as justice, work ethic, and respect for parents (Acs \& Dana, 2001); operating as hybrid institutions combining British law and Chinese customs (Cheng, Li, \& Ma, 2013); providing a vocational education system to transmit entrepreneurial knowledge and skills from successful to budding entrepreneurs (Loewen, 1971; Light, 1972; Wong, 1987; Dana, Etemad, \& Wright, 2000); responding to the growth of the nation-state and changing socio-political environment besides taking care of its members' needs (Chan, 2003); and organising religious ceremonies such as celebrating Chinese festivals, providing community representation, and arranging funerals and burials ( $\mathrm{Ng}$, 2002; Tan, 2018, p. 109) (Chan, 2019).

CSSYKL possesses both tangible and intangible heritage as defined by UNESCO. This is because it retains the original clan association building or ancestral hall, a fine example of Southern Chinese or Lingnan architecture, which is tangible heritage. Simultaneously, it also continues the tradition of ancestor worship and clan lineage among its association members, in following the 
Chinese Confucian norms of filial piety as well as community engagement, which is intangible heritage. It does not, however, possess the aspect of natural heritage.

The CSSYKL also has its headquarters in Guangzhou, Mainland China called the Chen Clan Ancestral Hall, upon which the Kuala Lumpur one is modelled, physically and organisationally. This hall initially functioned as an "academic temple" for candidates' preparation for the Qing Dynasty imperial examinations and was the template for the Chan See Shu Yuen built by its descendants in Malaysia. It prides itself on the inherited "Ling Nan Style of Architecture" derived from Guangzhou, Guangdong. The "CSSYKL building was modelled after the Chan Clan Association in Xi Guan, Guangzhou China as a design blueprint, which combined the characteristics of a family temple and an ancestral hall features, incorporating the ancient Cantonese-style art and Southern China architecture, which has a mix of Han and Bai Yue elements." (Chan See Shu Yuen Clan Association, 2016) (Chan, 2019a).

The CSSYKL has persisted in functioning ever since. "For more than a century, Chen's descendants of CSSYKL had kept the tradition alive and upheld its core values generation after generation. Celebration and paying homage for the birth commemoration of Chen's Great Grand Ancestors, Honourable Shun Di, Honourable Chen Shi, and Honourable Chen Yuan Guang, Spring and Autumn Festival Praying are the main occasion for CSSYKL. Other celebrations like CSSYKL anniversary, Lunar New Year, Duan $\mathrm{Wu}$, Lanterns Festival, Winter Solstice Festival, etc. will not be missed yearly. These everlasting practices of CSSYKL is likened to the immortal of incenses." (Chan See Shu Yuen Clan Association, 2016). The main hall is used for worship and paying homage to the Chen Clan Ancestors, which stretch back to China's civilisation from 5000 years ago. It also houses a mini-museum dedicated to preserving official documents regarding its founding and establishment, as well as examples of antique pottery and furniture. Upstairs, the office section has been rented out to a tuition teacher of Chinese ethnicity who conducts a Malay language class for primary and secondary school students. There is also an administrative office and a kitchen for the CSSYKL staff, comprising two administrators and several housekeepers (Chan, 2019a). 
Table 4: Comparison of Clan Association Functions Then and Now

\begin{tabular}{|c|c|c|}
\hline Features & $\begin{array}{c}\text { Past Features of Clan } \\
\text { Associations (Carstens, 1975) }\end{array}$ & $\begin{array}{c}\text { Present Features of Clan } \\
\text { Associations: } \\
\text { (Findings from fieldwork at Chan } \\
\text { See Shu Yuen) }\end{array}$ \\
\hline Functions & $\begin{array}{l}\text { The major activity is ancestor } \\
\text { worship } \\
\text { Provides welfare services for } \\
\text { beneficiaries of deceased } \\
\text { members, e.g. money, loan of } \\
\text { funeral requisites, and } \\
\text { attendance of fellow members } \\
\text { at the funeral } \\
\text { A few offer unemployment or } \\
\text { disability compensation } \\
\text { Provides scholarships for } \\
\text { needy children } \\
\text { Invests money from the sale of } \\
\text { association's property into a } \\
\text { separate organisation and } \\
\text { controlled by trustees } \\
\text { But does not give money to } \\
\text { charity and only provides for } \\
\text { members of the clan } \\
\text { Encourages the importance of } \\
\text { education } \\
\text { Used to assist members who } \\
\text { desired to return to China (but } \\
\text { has now ceased) } \\
\text { Welfare benefit assistance, } \\
\text { however, has decreased with } \\
\text { the increase in charitable } \\
\text { activities, e.g. raising money } \\
\text { for hospitals, schools, and old } \\
\text { folks' homes }\end{array}$ & $\begin{array}{l}\text { The major activities are a fund- } \\
\text { raising, charity, facilitating visits by } \\
\text { trade leaders and businesspeople } \\
\text { from abroad such as China or Taiwan, } \\
\text { hosting visits by local colleges, } \\
\text { hosting academic talks, as well as } \\
\text { ancestor worship. Also provides } \\
\text { scholarships for members. } \\
\text { For income generation purposes, an } \\
\text { ethnic Chinese Bahasa Malaysia } \\
\text { tuition teacher rents the upper floor } \\
\text { to conduct his classes. } \\
\text { There used to be Chinese language } \\
\text { classes conducted at CSSY but they } \\
\text { have now ceased as the teacher has } \\
\text { retired due to old age. } \\
\text { A great number of tourists come from } \\
\text { various European countries as well as } \\
\text { China and Malaysia itself. These are } \\
\text { recorded in CSSYKL's guest record } \\
\text { book, and also observed during } \\
\text { participant observation where tourists } \\
\text { trickle in daily with their cameras. } \\
\text { The CSSYKL has been listed as a } \\
\text { historical relic in the protection of } \\
\text { ancient buildings by the Malaysian } \\
\text { government (cssykl.com/ } 2018 \text { ). It was } \\
\text { also featured as one out of twelve } \\
\text { places to visit on a tourist trail, } \\
\text { designated by the Ministry of } \\
\text { Tourism and Culture of Malaysia } \\
\text { (Malaysia Tourism Centre, 2017). }\end{array}$ \\
\hline
\end{tabular}

(Source: Chan (2019a).) 
Thus, in Petaling Street, there are simultaneously two forms of heritage management among tourist sites which are the adaptive re-use of historical buildings; and the preservation and continued use of a historical building. CSSYKL represents the preservation of a historical building as can be seen from the functions outlined in Table 4, which persists.

\section{Discussion}

From the collection of tourist reviews on TripAdvisor, the following are the tourists' opinions on the effects of the buildings' design in the selected sites of observation:

\section{Table 5: Tourist Opinions on TripAdvisor}

\begin{tabular}{|c|c|c|}
\hline & Place & Tourist Opinions \\
\hline 1 & CSSYKL & $\begin{array}{l}\text { A. Free entry, nice temple } \\
\text { Really well kept and clean beautiful Chinese temple in KL's } \\
\text { Chinatown with some nice Chinese ornaments. Entry is free. } \\
\text { Date of experience: June } 2019 \\
\text { B. Exemplary and beautiful } \\
\text { Built in 1906, the complex in gray, red and gold colors is over } \\
\text { a century old and beautifully renovated. Well maintained by } \\
\text { members of the Chan clan. As far as I am concerned an } \\
\text { example for others to follow. } \\
\text { Beautiful carvings and sculptures, festive Chinese lanterns } \\
\text { and inside an altar enshrining the three main ancestors of the } \\
\text { Chan clan. A small informative room with photos and historic } \\
\text { details is part of the compound. } \\
\text { Free admission. } \\
\text { Date of experience: January } 2019 \\
\text { C. Really cool Clan House } \\
\text { If you do the Historical Centre of China Town Walking tour, } \\
\text { this is where things start off. I was amazed at the detail on this } \\
\text { temple, (built in 1906). I found it easy to find, right next to the } \\
\text { huge fountain from the } 1950 \text { s. } \\
\text { Date of experience: November } 2018\end{array}$ \\
\hline 2 & Hipster Cafe & $\begin{array}{l}\text { A. Cozy place } \\
\text { Right next to Petaling Street. The entrance does not say much } \\
\text { but once inside the place is beautiful, and the food is quite } \\
\text { good. } \\
\text { Date of visit: July } 2019\end{array}$ \\
\hline
\end{tabular}




\begin{tabular}{|c|c|c|}
\hline & & $\begin{array}{l}\text { B. FUN BRUNCH EXPERIENCE } \\
\text { You will never notice this place if you didn't do your research. } \\
\text { Hidden in the shophouse, entrance is a green wooden door. } \\
\text { They have divided the restaurant into } 3 \text { parts; each part seems } \\
\text { as though they have created different themes and owner have } \\
\text { tried to maximise the space. } \\
\text { Date of visit: June } 2019 \\
\text { C. Cute place to visit } \\
\text { We found this place on TA when researching hidden gems in } \\
\text { Chinatown. It is a gorgeous little cafe with a lovely } \\
\text { atmosphere and pleasant staff members. } \\
\text { Date of visit: June } 2019\end{array}$ \\
\hline 3 & $\begin{array}{l}\text { Street/back } \\
\text { lane }\end{array}$ & $\begin{array}{l}\text { (There was no TripAdvisor page for this newly rejuvenated } \\
\text { attraction, possibly because it was only very recently launched on } 11 \\
\text { April 2019. The closest equivalent to a reviews site was the } \\
\text { attraction's official Facebook page. Tourists left their } \\
\text { recommendation on the Facebook page): } \\
\text { A. Is good for a tourist visit } \\
\text { 16 Jun/June } 2019 \\
\text { B. - Utk foto keren, gambarnya keren (Translation: Makes for } \\
\text { cool photos) } \\
\text { - Destinasi tanpa biaya (Translation: A no-cost destination) } \\
\text { - tempatnya gampang dijangkau (Translation: Is an easily } \\
\text { accessible place) } \\
22 \text { Jun/June } 2019 \\
\text { C. A nice balance between conservation and restoration. } \\
\text { Providing the visitor a glimpse into old Malaya :) } \\
25 \text { Mei/May } 2019\end{array}$ \\
\hline 4 & $\begin{array}{l}\text { Tea house/ } \\
\text { restaurant }\end{array}$ & $\begin{array}{l}\text { A. For tea lovers... } \\
\text { Great place near the LRT Pasar Seni station. All kinds of tea } \\
\text { on offer, together with a whole host of tea relayed stuff (pots, } \\
\text { cups etc). } \\
\text { Date of visit: January } 2019 \\
\text { B. Cool place } \\
\text { The place is cool, very clean and has a really positive vibe }\end{array}$ \\
\hline
\end{tabular}




\begin{tabular}{|l|l|}
\hline $\begin{array}{l}\text { With people painting and relaxing. } \\
\text { Date of visit: November } 2018\end{array}$ \\
$\begin{array}{l}\text { C. All about teas } \\
\text { the place is now at the ground floor, at the end lot facing the } \\
\text { Pasar Seni LRT station, outside was decorated with lovely } \\
\text { benches and garden to seat, good packaging for teas and } \\
\text { interior design here. } \\
\text { Date of visit: March } 2018\end{array}$ \\
\hline
\end{tabular}

In the comments garnered from the tourist reviewers, it appears that the design of a place affects their touristic experience. This is naturally obvious with areas such as the CSSYKL building and the rejuvenated back lane, whose qualities are most tangible. However, reviewers often mentioned this aspect alongside their reviews of the food and service quality even when the outfit is food and beverage-oriented one. The ambience such as "people painting and relaxing" also adds value to the overall tourist experience in a cafe. An interest in photogenic locations is also observed through the comment "Makes for cool photos", where the touristic value of a place can sometimes be measured through its "Instagram-worthiness", as outlined in Figure 1.

Figure 1: Conceptual Framework of Heritage-Based Tourist Attraction
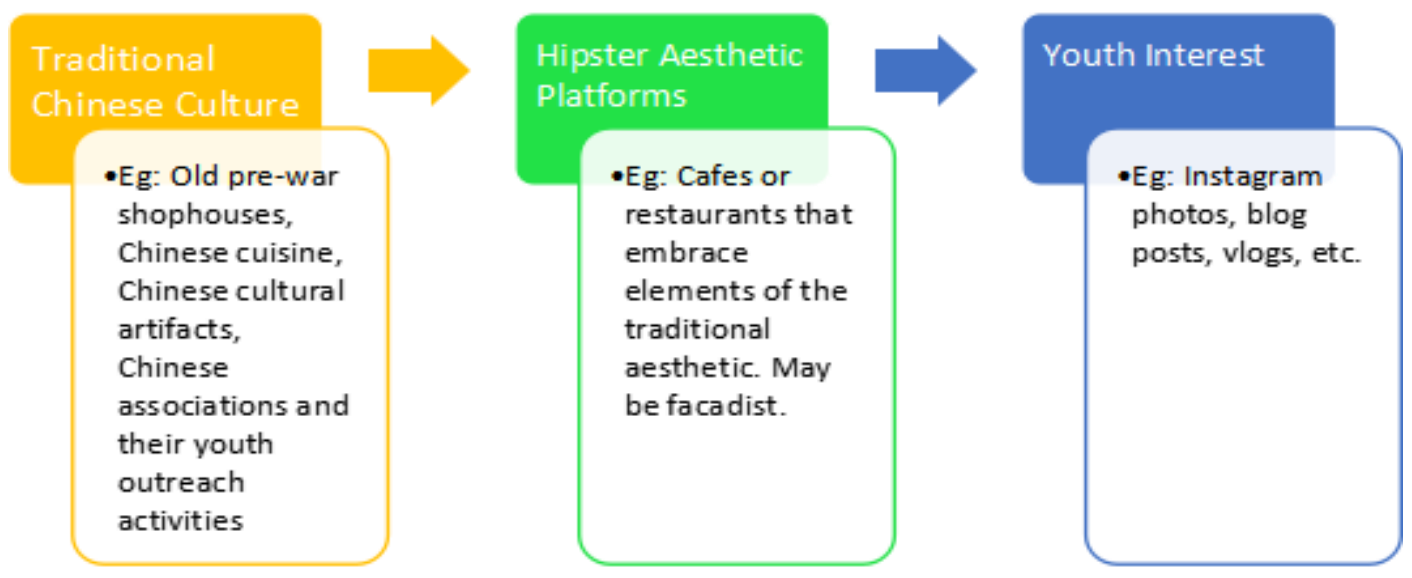

There is an apparent process in which traditional and historical aesthetics have become popularised as a trend among consumer youth. For example, traditional Chinese cultural practices such as Chinese tea rituals are offered in some of these themed restaurants which are housed in adaptive re-use buildings. The 
contemporary décor of these buildings is embedded in their historical facades, which in turn derive influences from a variety of sources, including Western and Chinese origins. Consumer youth, many of which are hipsters, both discover these places and popularise them through social media where they act as influencers, as well as discover them through social media as followers. These historical places, with their newly acquired trendy vintage aesthetic, resonate well with the hipster crowd who are always in search of something "not too mainstream". This aesthetic appreciation also overlaps with the rise of "ruin tourism", or public interest in "industrial ruins, abandoned places and landscapes of urban decay", which is also "widely circulated through various social media platforms and online networks; enacted by such groups as urban explorers, ruin tourists and heritage tourists" (Jansson, 2017). Some consumer youth are observed being willing to queue up for long periods to get a seat at some of these outfits. The vintage aspect of these places suggests a non-conformist bent, separate from the reach of consumerism. Of course, whether this is truly the case is up for debate, as one may well argue that social media influencers are yet another capitalist ideological tool where the consumers are co-opted into marketing the product. As Le Gallou (2018) found, "ruin tourism" can be viewed as "new practice of urban tourism based on the reappropriation and commodification of alternative practices developing in marginalised urban areas".

Table 4: Matrix of Community Participation in Cultural Heritage Management among Petaling Street Tourist Sites

\begin{tabular}{|c|c|c|}
\hline & $\begin{array}{c}\text { Membership-based } \\
\text { (Intangible heritage which is } \\
\text { association-based) }\end{array}$ & $\begin{array}{c}\text { Market-based } \\
\text { (Tourist or customer demand) }\end{array}$ \\
\hline $\begin{array}{l}\text { Adaptive Re- } \\
\text { use }\end{array}$ & $\begin{array}{l}\text { Probably not viable since } \\
\text { adaptive re-use itself suggests } \\
\text { a change of ownership. }\end{array}$ & $\begin{array}{l}\text { Pre-war buildings formerly used } \\
\text { for other purposes e.g. } \\
\text { hotels/brothels, now re-used as } \\
\text { cafes but with the original façade } \\
\text { maintained as part of the } \\
\text { attraction. }\end{array}$ \\
\hline $\begin{array}{l}\text { Continuous } \\
\text { Preservation }\end{array}$ & $\begin{array}{l}\text { Chan See Shu Yuen Kuala } \\
\text { Lumpur \& Selangor clan } \\
\text { association } \\
\text { (CSSYKL). }\end{array}$ & $\begin{array}{l}\text { Pre-war back lanes rejuvenated } \\
\text { as a photo-friendly tourist } \\
\text { hotspot. }\end{array}$ \\
\hline
\end{tabular}




\section{Conclusion}

From Table 6, it is observed that there is a matrix of heritage management in Petaling Street's tourist sites. The Asian approach to heritage management differs from the dominant Western one, in that it recognises ways and means of preserving cultural heritage with community participation and different understandings of heritage that exist outside of Europe (Nagaoka, 2015). In this study, the two most apparent community approaches are that of adaptive re-use and continuous preservation of historical buildings. Continuous preservation is enabled by the continued membership of associations such as CSSYKL because this aspect preserves its ownership within the association. Thus, it does not need to be replaced in ownership nor function. This is the advantage of having intangible heritage nested within the tangible heritage, as in the case of the clan association having a membership which continues to practice Confucian traditions which are adjusted to accommodate a society experiencing superdiversity. However, for buildings devoid of intangible cultural heritage, the status of ownership changes through the machinations of market demand. It is thus more likely to be preserved using the method of profitable adaptive re-use. This, in turn, requires serious attention to be paid to compatibility factors such as safety, natural lighting, fire hazards, and others.

\section{Acknowledgement}

This research is supported by the Ministry of Education of Malaysia under Grant Number FRGS/1/2018/WAB12/UKM/02/1 (Superdiversity Networks: Cantonese Clan Associations in Malaysia as Transnational Social Support System). Parts of this research have been presented in conferences.

\section{References}

Acs, Z. J., \& Dana, L. P. (2001). Contrasting two models of wealth redistribution. Small Business Economics, 16(2), 63-74.

Al-Obaidi, K., Sim, L. W., Muhammad Azzam Ismail, \& Kam, K. (2017). Sustainable building assessment of colonial shophouses after adaptive reuse in Kuala Lumpur. Buildings, 7(4), 87.

Adlin Baizura Ariffin, Mohd. Salehuddin Mohd. Zahari, Salleh Mohd. Radzi, \& Mohd. Zain Kutut. (2017). Adaptive reuse of historical buildings and local residents' actual visitation. Journal of Tourism, Hospitality \& Culinary Arts, 9(2), 35-46. 
Azizah Kassim, Too, T., Wong, S. C. M., \& Mahani Zainal Abidin. (2014). The management of foreign workers in Malaysia: Institutions and governance regime. In R. H. Adams Jr. \& Ahmad Ahsan (Eds.), Managing international migration for development in East Asia (pp. 241-262). Washington, DC: World Bank.

Bromley, R. D., Tallon, A. R., \& Thomas, C. J. (2005) City centre regeneration through residential development: Contributing to sustainability. Urban Studies, 42(13), 2407-2429.

Bullen, P. A., \& Love, P. E. (2011). Adaptive reuse of heritage buildings. Structural Survey, 29(5), 411-421.

Carstens, S. A. (1975). Chinese associations in Singapore society: an examination of function and meaning. Occasional Paper No. 37. Singapore: Institute of Southeast Asian Studies.

Chan, R. S. K. (2018a). Breaking windows: Malaysian manga as dramaturgy of everyday-defined realities. JATI-Journal of Southeast Asian Studies, 23(2), 205-229.

Retrieved

from https://jati.um.edu.my/index.php/jati/article/view/15419

Chan, R. S. K. (2018b). In between worlds: The convergence of Chinese and Western values as global habitus. JATI-Journal of Southeast Asian Studies, 23(1), 156-190. Retrieved from https://jati.um.edu.my/index.php/jati/article/view/12191

Chan, R. S. K. (2018c, 2-3 October). Super-diversity and the intersectionality of urban spikiness. Paper presented at Towards Livable, Resilient \& Competitive Cities International Conference 2018 (TLRCC), University of Malaya, Kuala Lumpur, Malaysia.

Chan, R. S. K. (2018d, 1-2 December). The shape of nationalism in Malaysia: where do we stand? Paper presented at the Conference on Strengthening Nationhood 6: (COSNA 6) Regional Building of ASEAN Identity 'Integration the Way Forward', KITA-Universiti Sultan Zainal Abidin, Terengganu, Malaysia.

Chan, R. S. K. (2019a). Chan See Shu Yuen: A Cantonese ancestral clan in Malaysia as transnational social support network. In C. Gambardella (Ed.), World heritage and legacy: Culture, creativity, contamination (Le Vie dei Mercanti XVII International Forum) (pp. 354-363). Rome: Gangemi Editore International Publishing. Retrieved from https://www.gangemieditore.com/dettaglio/world-heritage-andlegacy/8432/2

Chan, R. S. K. (2019b). Cities and culture: The case for cultural heritage preservation in the era of superdiversity. Asia Proceedings of Social 
Sciences, 4(1), 115-117. Retrieved from http://readersinsight.net/APSS/article/view/586/535

Chan She Shu Yuen Clan Association. (2016). Glory days relived: 120 years of Chan She Shu Yuen. Kuala Lumpur: Chan She Shu Yuen Clan Association.

Chan, S. C. (2003). Interpreting Chinese tradition: A clansmen organisation in Singapore. New Zealand Journal of Asian Studies, 5(1), 72-90.

Cheng, E. W., Li, A. H. F., \& Ma, S. Y. (2013). Resistance, engagement, and heritage conservation by voluntary sector: The case of Penang in Malaysia. Modern Asian Studies, 48(3), 617-644.

Ch'ng, C. L. D. (1995). Sukses bisnis Cina perantauan. Latar belakang, praktek bisnis dan jaringan internasional. Jakarta: Pustaka Utama Grafiti.

Dana, L. P., Etemad, H., \& Wright, R. W. (2000). The global reach of symbiotic networks. In L. P. Dana (Ed.), Global Marketing co-operation and networks (pp. 1-16). Binghamton, NY: International Business Press.

Dysart, H. A. (2006). One stop community center-Adaptive reuse of a vacant WalMart. Master's thesis, University of Nebraska - Lincoln, Lincoln, Nebraska, United States. Retrieved from http://digitalcommons.unl.edu/archthesis/26

Elnokaly, A., \& Wong, J. F. (2015). Demystifying vernacular shop houses and contemporary shop houses in Malaysia: A green-shop framework. In Proceedings of the 30th International PLEA Conference 2014 (pp. 295-303). Ahmedabad: CEPT University.

Guelden, M. (1986). Kuala Lumpur. Singapore: The Times Travel Library.

Harun, S. N. (2011). Heritage building conservation in Malaysia: Experience and challenges. Procedia Engineering, 20, 41-53.

Jansson, A. (2017, 5-7 April). "This is not ruin tourism": Exploring the spreadable city. Paper presented as keynote at the Locating Imagination Conference, Rotterdam, the Netherlands.

Kirshenblatt-Gimblett, B. (2004). Intangible heritage as metacultural production. Museum International, 56(1-2), 52-65.

Lam, S. F. (2004). Insider's Kuala Lumpur. Singapore: Times Editions Marshall Cavendish.

Latham, D. (2000). Creative Re-Use of Buildings. Shaftesbury: Donhead Publishing Ltd.

Le Gallou, A. (2018). From urban exploration to ruin tourism: A geographical analysis of contemporary ruins as new frontiers for urban tourism. International Journal of Tourism Cities, 4(2), 245-260.

Light, I. (1972). Ethnic enterprise in America: Business and welfare among Chinese, Japanese, and Blacks. Berkeley, CA: University of California Press. 
Loewen, J. W. (1971). The Mississippi Chinese: Between black and white. Cambridge, MA: Harvard University Press.

Malaysia Tourism Centre. Launching KL Must Visit Attractions Trail Card (19 Oktober

http://www.matic.gov.my/en/information/gallery/photo/291 -launchingklmust-visit-attractions-trail-card-19-oktober-2017

Mahsa Mansouri, \& Norsidah Ujang. (2016). Tourist expectation and satisfaction towards pedestrian networks in the historical district of Kuala Lumpur, Malaysia. Asian Geographer, 33(1), 35-55.

Mariana Makmur. (2018). The Chinese clan associations in Padang: A package of the ethnic tradition and the social-culture change in the era of globalization. IOP Conference Series: Earth and Environmental Science, 126, $1-9$.

Nagaoka, M. (2015). 'European' and 'Asian' approaches to cultural landscapes management at Borobudur, Indonesia in the 1970s. International Journal of Heritage Studies, 21(3), 232-249.

$\mathrm{Ng}$, C. K. (2002). An outline of the recent development of clan associations in Singapore. ihakka.net. Retrieved from http://www.ihakka.net/DOC/An\%20Outline\%20of\%20the\%20Recent\%20 Development $\% 20$ o f\%20Clan \%20Associations\%20in \%20Singapore\%E5\%90\%B3\%E6\%8C\%A F\%E5\%BC\%B7.doc

Orbasli, A. (2009). Re-using existing buildings towards sustainable regeneration (School of Architecture: Place and Culture Identity Group Working Paper). Retrieved from: http://www.aylinorbasli.com/Resources/Reuse\%20and\%20sustainability \%20Orbasli.pdf

Parham, S. (1996, October). Gastronomic architecture: The cafe and beyond. Architecture Bulletin.

Richards, J. (1994). Facadism. London: Routledge.

Ryan, J., \& Silvanto, S. (2009). The World Heritage List: The making and management of a brand. Place Branding and Public Diplomacy, 5(4), 290300.

Salleh, N. H., \& Ahmad, A. G. (2009, 11-15 October). Fire safety management in heritage buildings: The current scenario in Malaysia. Paper presented at the 22nd CIPA Symposium, Kyoto, Japan.

Shahrul Yani Said, Hasnizan Aksah, \& Elma Dewiyana Ismail. (2013). Heritage conservation and regeneration of historic areas in Malaysia. ProcediaSocial and Behavioral Sciences, 105, 418-428. 
Shamsul Amri Baharuddin, \& Athi S.M. (2013). Ethnicity and identity formation: Colonial knowledge, colonial structures and transition. In M. L. Weiss (Ed.), Routledge handbook of contemporary Malaysia (pp. 267-278). Oxford: Routledge.

Smith, M. K. (2003). Issues in cultural tourism studies. London: Routledge.

Sun, W. N. (2005). Media and the Chinese diaspora: Community, consumption, and transnational imagination. Journal of Chinese Overseas, 1(1), 65-86.

Tan, C.-B. (2018). Deities, speech groups and temples. In C.-B. Tan, Chinese religion in Malaysia: Temples and communities (pp. 30-48). Leiden: Brill.

Toong, Y. S., \& Utaberta, N. (2015). Heritage buildings conservation issues of shophouses in Kuala Lumpur Chinatown. Applied Mechanics and Materials, 747, 60-63.

United Nations Educational, Scientific and Cultural Organization (UNESCO). (2016). Culture, urban future: Global report on culture for sustainable urban development. Paris: UNESCO.

Wan Abdullah Zawawi Noor Amila, \& Alias Abdullah. (2013). Evaluating stakeholders' preferences: reconciling heritage and sustainability. International Journal of Sustainable Society, 5(4), 336-349.

Wan Abdullah Zawawi Noor Amila, \& Alias Abdullah. (2008, 3-6 November). Urban heritage conservation through redevelopment strategies: A case study of Kuala Lumpur. Paper presented at the Third International Conference of the Center for the Study of Architecture in the Arab Region (CSAAR 2008A), Amman, Jordan.

Wan Hashimah Wan Ismail, \& Jegenth Raj s/o Nadarajah. (2016). Young visitors in the city: Their perceptions of heritage buildings. Procedia-Social and Behavioral Sciences, 234, 470-477.

Wilkinson, S. J., \& Reed, R. G. (2008). The business case for incorporating sustainability in office buildings: the adaptive reuse of existing buildings. In PRRES 2008: Investing in Sustainable Real Estate Environment (Proceedings of the 14th Annual Conference of the Pacific Rim Real Estate Society) (pp. 1-18). Retrieved from http://www.prres.net/

Wilkinson, S., James, K., \& Reed, R. (2009). Delivering sustainability through the adaptive reuse of commercial buildings: The Melbourne CBD challenge. In PRRES 2009: Proceedings of the Pacific Rim Real Estate Society 15th Annual Conference (pp. 1-19). Retrieved from http://www.prres.net/

Wong, B. (1987). The role of ethnicity in enclave entrepreneurs: A study of the Chinese garment factory in New York City. Human Organization, 66(2), 120-130. 
Wong, S. F. (2011). Walkability and community identity in the city centre of Kuala Lumpur. Ph.D. thesis, Faculty of Architecture, Building and Planning, University of Melbourne, Melbourne, Australia. Retrieved from https://minerva-access.unimelb.edu.au/handle/11343/36386

Vertovec, S. (1997). Three meanings of "diaspora", exemplified among South Asian religions. Diaspora: A Journal of Transnational Studies, 6(3), 277-299.

Vertovec, S. (2007). Super-diversity and its implications. Ethnic and Racial studies, 30(6), 1024-1054.

Yacob Omar, \& Nor Haniza Ishak. (2009, 11-14 May). Preventive maintenance management: An approach towards a sustainability of adaptive re-use historical buildings in Kuala Lumpur, Malaysia. Paper presented at the International Engineering Convention, Damascus, Syria.

Yen, C.-H. (1981). Early Chinese clan organizations in Singapore and Malaya, 1819-1911. Journal of Southeast Asian Studies, 12(1), 62-91.

Date Received: 30 August 2019 Date of Acceptance: 15 December 2019 